\title{
Transatlantica
}

Revue d'études américaines. American Studies Journal

\section{Interview with Maya Sonenberg conducted in} 2012-2013.

\section{Monica Manolescu}

\section{(2) OpenEdition}

1 Journals

\section{Édition électronique}

URL : https://journals.openedition.org/transatlantica/6053

DOI : $10.4000 /$ transatlantica.6053

ISSN : $1765-2766$

Éditeur

Association française d'Etudes Américaines (AFEA)

Référence électronique

Monica Manolescu, « Interview with Maya Sonenberg conducted in 2012-2013. », Transatlantica [En ligne], 2 | 2012, mis en ligne le 21 juin 2013, consulté le 06 avril 2023. URL : http://

journals.openedition.org/transatlantica/6053 ; DOI : https://doi.org/10.4000/transatlantica.6053

Ce document a été généré automatiquement le 6 avril 2023.

\section{(c)}

Creative Commons - Attribution - Pas d'Utilisation Commerciale - Pas de Modification 4.0 International - CC BY-NC-ND 4.0

https://creativecommons.org/licenses/by-nc-nd/4.0/ 


\title{
Interview with Maya Sonenberg conducted in 2012-2013.
}

\author{
Monica Manolescu
}

Maya Sonenberg is the author of two collections of short fiction: Cartographies, University of Pittsburgh Press, 1989(winner of the Drue Heinz Literature Prize) and Voices from the Blue Hotel, Chiasmus Press, Portland, 2007. She attended Brown University's Creative Writing Program, where she studied with John Hawkes, Robert Coover, and Susan Sontag.She teaches creative writing at the University of Washington, Seattle.

Monica Manolescu: What is the meaning of your "cartographies" ? What attracts you in maps and mapmaking?

Maya Sonenberg : Like a map, fiction has an uneasy relationship with the world as we live in it and experience it, not completely disconnected from that world but also neither a window onto that world nor a mirror of that world. Perhaps map and fiction are more like the mirror through which Alice enters Wonderland. In Jorge Luis Borges' story "Of Exactitude in Science," the cartographers in a distant and ancient empire developed a "Map of the Empire that was of the same Scale as the Empire and coincided with it point for point," but later generations discarded this map as too cumbersome. I would pose that such a map, if it existed, would still, in some sense, be unlike the world which it purports to describe, despite all its points of identity. Like a map, the language of fiction refers to the "real" world and to itself simultaneously. Like a map, a story is both the portal to an imagined world and an imagined world. The friction between these simultaneous and seemingly contradictory feelings and understandings is magical.

$\mathrm{MM}$ : When does "cartography" become a literary genre in itself ?

MS : Long before I was writing-or born!-Borges wrote about the mystical and magical properties of maps, as well as similar items such as atlases, encyclopedias, and libraries. 
MM : Why not use the word "mapping" instead of "cartography" ?

MS : I think the plural of "mapping" (mappings) just sounded awkward to me, and the title definitely needed to be plural, not just one "mapping," but the idea that multiple "mappings" or versions or points of view are necessary.

MM : Is the act of naming what brings writers close to mapmakers ? Or the fact of creating worlds ? Or both?

MS : The act of naming claims something that already exists and is the purview of Adam, while the creation of a world crafts something out of nothing and is the purview of God-at least according to the Old Testament. I suppose that most would align mapmaking with naming-a labeling of the world that exists outside language, outside our brains and imaginations-but my experience of the relationship between looking at a map and visiting the world that map names has never been obvious or clear-cut. Each time I visit a place I have only previously experienced on a map, I have a moment of vertigo because I recognize the ways in which the map has failed to name that world and has instead allowed me to create a world in my mind.

MM : Are there significant examples of maps or books about maps or literary texts dealing with maps that have inspired your work?

MS : All maps, from the giant Rand-McNally Atlas my children consult for school projects to Google maps on my smart phone to the map of Middle Earth at the start of Tolkien's Lord of the Rings work to open my imagination and so are inspiring to the act of writing. Recent literary works that focus on maps in interesting ways are Judith Schalansky's Atlas of Remote Islands, Rebecca Solnit's Infinite City : A San Francisco Atlas, and Denis Wood's Everything Sings : Maps for a Narrative Atlas.

MM : In the short story that opens Cartographies, we find indications about how to map our "favorite mountain" : one should walk around it, climb upon it, take pictures of it from an airplane, make a clay model of it at home and then "flatten it". Would you care to comment on that passage?

MS : In the story, the passage you quote is followed by two other sections that also begin with the phrase "To make a map of your favorite mountain." While this first passage focuses on a series of routine physical actions that might lead from the "real" to the "represented," the second passage works in the opposite direction, directing the reader to look at other maps of the mountain, create a personal key for the map noting favorite spots, and finally to create indications on the "real" landscape aligning it with the represented one. The final instructional passage guides the reader to link his/her mountain map to the forces of geological time and human history. The impulse here is to complicate and question the idea of map-making, showing how an object we may perceive as simple and clear-a map-is both formed by and forms personal and historical experiences.

MM : What are the links between art and cartography that you are exploring in the book? In "Dioramas" you refer to many kinds of artistic representation: landscape painting, dioramas, knitted patterns, pottery. "Nature Morte" talks about "the first cubist baby born to 
an unwed mother from Avignon" in 1911. Renaissance portraiture also features in "June 4, $1469 "$.

MS : A map is a visual representation, as a still life or landscape or portrait are visual representations, and like these representations which are more often considered "artistic," maps also come into being through their creators' individual and cultural backgrounds-we just don't often think of them that way. Like a still life by Cézanne, the Mercator projection presents a distorted version of the physical world. I do not mean to pass judgment by using the word "distorted"-or perhaps I mean to suggest a positive judgment : these distortions are simply facts, inescapable aspects of any attempt to render the lived world. It's these distortions that make all art interesting.

Sometimes the visual inspirations for my stories are obvious-the cubism of "Nature Morte" or the Italian Renaissance paintings of "June 4, 1469"-but in other stories, the original inspiration has metamorphosed into something more abstract or more structural. In "Dioramas" for example, I was heavily influenced by the art and writing of sculptor Robert Smithson and his ideas about landscape. In thinking about Smithson's work, I realized that, despite myself, several of my stories relied on rather Romantic, $19^{\text {th }}$ century notions of landscape and nature as existing in opposition to the man-made and serving to "heal" humans from their own propensity for the hardedged, the clear-cut, the intellectual : nature = good, man-made = bad. of course, nature is not always sweet and doesn't exist in order to "heal" humans! Thinking about Smithson's work led me to explore other ways fiction might engage with nature.

MM : Landscapes tell stories ("Landscape could be the story of our life", "Dioramas", 139), but your stories are also intensely visual. How do you navigate between language and image?

MS : From the start, I was interested in writing about art-not just visual art but all art forms-without writing criticism. An early story-now lost-centered on descriptions of a performance by artist Theodora Skipitares in which she wore a skirt made of fresh fish. For years I tried to write a story that might parallel the rhythms and feelings experienced at a punk rock show. It's true that over the years, I have most often concentrated on the visual arts-both of my parents were painters and I grew up looking at art as much as reading, going to museums and galleries as often as libraries. I don't think that I consciously attempt to navigate between these realms. Sometimes I experience them as equivalents; sometimes I try to create verbal equivalents for the visual. By an "equivalent," I don't just mean a description of a scene, object, character, slant of light, painting, etc., although I do often include straightforward descriptions. I might instead try to mimic the form of a painting in the form of a story-what's in the foreground, what's in the background, is the image Cubist or Impressionistic, Classical or Romantic?

MM : Many of your texts do not have plots in the conventional sense. They are highly lyrical and meditative. Do you think of them as poems?

MS : While my stories certainly arise more often from a lyric impulse than a narrative one, I do think of them as stories rather than poems. Even the most lyrical of my stories retain some interest in fictional characters and gesture towards plot. By "lyric," I mean that the fiction proceeds most often through the repetition and variation of images and that sound and rhythm (prose rhythms) are used to help 
create the focus or meaning of the piece. Several of the stories in Cartographies are really collage works, and so have an affinity for the visual arts as well as the poetic ones. Recently I have written a series of stories using traditional verse forms, the sestina, villanelle, sonnet and others, but I continue to think of even these works as stories rather than poems.

MM : "Ariadne in Exile" is a rewriting of the myth of Ariadne. What drew you to that myth and what is the thread that connects your Ariadne to mapmaking?

MS : I'm not sure I remember what drew me to this particular myth, except that it seemed ripe for a feminist reinterpretation. At the time I wrote this, I was interested in myths in general, in retelling old stories as a post-modern approach to writing fiction. Also, since I'm not much of a plot developer myself, I've always found it handy to use pre-existing plots. Doing so allows me to focus on other aspects of fiction that interest me more. I still turn to old stories in writing my new ones, although these days they are more likely to be fairy tales than myths. I'm not sure that the connection between the Ariadne myth and mapmaking was apparent to me at the time, although one can certainly see connections between Theseus's use of the string in the labyrinth and the creation of a map of that space. He'll use the string to return "home," as one might use a map.

MM : You make repeated use of imperatives in your stories : see the beginning of "Interval", but also "Cartographies" and elsewhere. What draws you to the imperative?

MS: The imperative immediately involves the reader since it implies the second person : you walk into a strange room and flip the light switch. It's a way to engage the reader viscerally and also to remind the reader that what they're reading is a construct. I am always interested in balancing right on that line between absorbing the reader completely in the work of fiction and reminding the reader that he/she is reading fiction.

$M M$ : What writers do you have affinities with?

2 MS : It feels presumptuous to claim affinities with the following amazing writers, so I've recast this as a list of writers whose work I consistently find inspiring (in no particular order) :

Henry James for the slipperiness of his sentences. Michael Martone for his playful and highly conscious use of forms and the sheer beauty of many of his sentences. Virginia Woolf, obviously. Angela Carter and Kate Bernheimer for their engagement with fairy tales. Jorge Luis Borges for his willingness to start a story with an intellectual premise. Kelly Link for her impeccable integration of the mundane and the fantastic. David Mitchell. W.G. Sebald. Michael Kimmelman for his essays which combine astute writing about art with astute writing about himself looking at the art. Joy Williams. Brian Evenson. Mary Caponegro. Kathryn Davis. Emily and Charlotte Brontë. The Charles Dickens of Bleak House. My teachers Robert Coover, John Hawkes, and Meredith Steinbach. Carole Maso, Joanna Scott, C.D. Wright. There are many many more whom I'm sure to remember as soon as I submit this, but these are the writers I return to, the writers whose new books I must buy as soon as they come out.

MM : I know you are very much interested in artists' books. Could you tell us a few words about how you are using artists' books in your creative writing teaching, how students 
respond to your assignments, and how the materiality of the book influences the writing itself. Also, do you have any projects around artists' books yourself?

MS : Although I have known about artists' books for as long as I can remember, I became seriously interested in the possible relationships between images and text when I first read Carole Maso's novel The Art Lover. For the first time, I saw a book of fiction in which images were employed as part of the text rather than illustrations of it. Of course, this interest deepened when I became acquainted with the work of W. G. Sebald. In 1997, I was working on an article about such books when I stumbled upon my university's amazing book arts collection which contains thousands of works, ranging from beautifully produced but ultimately conventional editions of poetry to one-of-a-kind sculptural works. I also met our book arts librarian, Sandra Kroupa, and we have now team-taught a number of classes incorporating book arts. The most recent (and most successful) iteration is an intermediate level undergraduate prose writing class which focuses on the relationship between form and content. In it, students first study and write a conventional narrative; move on to read and write more experimental fiction based on forms of music, collage, essay, newspaper article, or Russian nesting doll; and finally write and make a book in the form of an accordion or loose cards in which the text must interact successfully with the physical form. Most students love this class because it challenges them, but also because I think I've structured it very carefully and am very clear about how the readings and writing assignments contribute to the focus of the class. Some students, however, remain antagonistic to the idea of making a book, insisting that physical form has no effect on text or that these explorations should be left to "art" classes. What I've found most interesting is that some students whose writing on its own isn't that strong, come up with really wonderful final projects-not just visually pleasing but complex and thoughtful projects. In other words, it isn't just that some students are more skilled in the visual arts than the written word, or that some students have more experience making visual art than others, but that these different assignments may encourage or tap into different sources of creativity. In terms of my own writing, as I mentioned above, I've started incorporating visual elements into my stories and essays-manipulated family photographs, diagrams, drawings.

$\mathrm{MM}$ : What are you working on right now?

MS: I have just finished a collection of stories which ask questions like "what happens when the urge to ditch your family equals the desire to love them ?" or "what happens when love for one family member overwhelms love for another ?" For me, these challenging questions lead to really messy emotions, and so the collection experiments with a variety of forms to both express and control those feelings. While the collection uses collage forms and other non-story structures such as the letter, the list, and the essay, the primary structures it employs are traditional verse forms. In one story, the "turn" in the final couplet of a sonnet embodies regret. In another, the insistent repetitions of a villanelle become the pressures of listening to a parent with dementia and a toddler at the same time. In a third, the looping repetitions of a pantoum haunt a woman cleaning out her dead mother's apartment. In another, the form of a five-paragraph essay forces a mother to develop the thesis that she loves one of her children more than the others. I am also working on a series of essays linking my actual ancestors to my literary ancestors-family history to writing I find influential or disturbing-and combining memoir, family history, tales, quotations, and close readings with visual elements (drawings, manipulated photographs, 
diagrams). The first completed essay, "Models for Raising the Dead," begins by focusing on a single sentence by from an essay by Charles D'Ambrosio and a single line from one of Richard Hugo's poems, and adds quotes from Gertrude Stein and from $19^{\text {th }}$ century texts on grammar and medicine, snippets of memoir and tale, meditations on images from $9 / 11$, ruminations on a year during which many friends and former teachers died, and visual knitting and sentence diagrams to investigate our experiences of loss and our simultaneous need to create order out of misery. Another essay will peer through Henry James' The Golden Bowl and my mother's secrets into the difference between maintaining privacy and keeping secrets in the digital age. Another will explore my love for the Little House books by Laura Ingalls Wilder and my own grandmother's immigration west, from Russia to New York. 